Original Research

\title{
Host Specificity, Community Components and Diversity Dynamics of Dactylogyrus spp. (Monogenean ectoparasites) Parasitizing Cyprinid Gills
}

\author{
Qaraman Koyee $^{1 *}$, Shamall Abdullah ${ }^{2}$ \\ 'Biology Department, Zoology Research Laboratory, Science College, Salahaddin University, Erbil, Iraq \\ ${ }^{2}$ Fish Resource and Aquatic Animal Department, Agriculture College, Salahaddin University, Erbil, Iraq
}

Received: 17 July 2018

Accepted: 21 November 2018

\begin{abstract}
Habitually, gills of cyprinid fish have deemed the natural habitats of Dactylogyrus spp. worldwide. Taxonomically, this common monogenean ectoparasite belongs to the Dactylogyridae family. It could be mentioned that the current study is the first comprehensive attempt at highlighting the host specificity of this flatworm parasite that affects Iraqi freshwater fish. Moreover, community components of the parasite and diversity dynamics are also elaborated upon. A total of 681 fish belonging to 18 species (Cyprinidae family) were collected in the Lesser Zab River from August 2016 to July 2017. The fish were examined monthly for diversity fluctuation and abundance in communities of gill Dactylogyrids species, host specificity, fish length, and fish weight. The results revealed the presence of 21 Dactylogyrid species, including 10 specialists and 11 generalists. Among them, the highest richness mean (252) was documented for D. carassobarbi, while the highest prevalence percentage (44.44\%) was recorded for D. pavlovskyi. On the other hand, the highest mean community abundance (35.7) and mean parasite community species richness (464) were observed for D. kersini. There were no significant differences in host specificity for infested fish total lengths and weights. Regarding seasonal variations, the highest Dactylogyrid species richness was in March 2017. Most species abundance was reported on gill numbers II and III for both sides.
\end{abstract}

Keywords: species richness, Cyprinids, prevalence, host specificity, Dactylogyrus spp.

\footnotetext{
*e-mail: qaraman.koyee@su.edu.krd,
} mamakhidr@yahoo.com 


\section{Introduction}

The most diverse and widespread freshwater fish family is Cyprinidae, which contains more than 2400 species (220 genera). It represents about $8.5 \%$ of the world's fish and dwells naturally in all types of habitats. This family contains the most abundant species in Iraqi freshwater, where native fish occupy $72 \%$ of the whole fish populations [1,2].

Cyprinids have been adapted to carry species of Dactylogyrus Diesing, 1850. This Cyprinid gill inhabitant is one of the most critical genera and it comprises more than 900 species [3]. So the rampancy of this enormous parasitic individual in various aquatic environments justifies the high range of their cyprinid hosts and specificity. For instance, many Dactylogyrus species (spp.) are specific to a single host species or congeneric hosts [4].

According to host specificity of Dactylogyrus spp., they frequently exhibit strict, congeneric or phylogenetic host specificity. The abundance of Dactylogyrus spp. on their cyprinid hosts explains the fish origin [4, 5]. Little is known about Dactylogyrus spp. attacking the cyprinid hosts in the Mediterranean area, but a few types of research have suggested that - owing to high host specificity - the abundance of Dactylogyrus spp. follows the endemism of their cyprinid species [6].

Currently, the parasitic fauna of fish in the Kurdistan region of northern Iraq represents 188 valid species inhabit and parasitise 27 valid freshwater fish cyprinid species in different localities. Overall, 82 species of monogeneans were reported, from which 47 species of Dactylogyrus, in addition to unidentified species named
Dactylogyrus spp., which is by far the largest among the Monogeneans [7, 8].

The present study objectives are to determine the prevalence, abundance, community components, species richness, and monthly fluctuations of Dactylogyrus spp. Furthermore, it was also necessary to investigate the correlation of such host factors as body weight, standard length, sample size, sex, and host specificity, which probably influence the infestation severity of the parasite.

\section{Materials and Methods}

\section{Description of Study Area}

The study area is situated on the banks of the Lesser Zab River from northeastern Iraq at Altun-Kopru (Prde) town. It is $40 \mathrm{~km}$ northwest of Kirkuk and $50 \mathrm{~km}$ from Erbil (Fig. 1). The river is located between $34-36^{\circ}$ north latitude and $43-46^{\circ}$ east longitude and originates in Iran [9].

\section{Fish Collection and Identification}

A total of 681 fish were collected weekly by resident commercial fishermen with gill netting throughout a period starting in August 2016 and ending in July 2017. The specimens were brought to the Zoology Research Laboratory, Biology Department, College of Science, Salahaddin University in Erbil using a container with local river water and dissected within 24 hours after their collection. All fish were categorized into 18 species

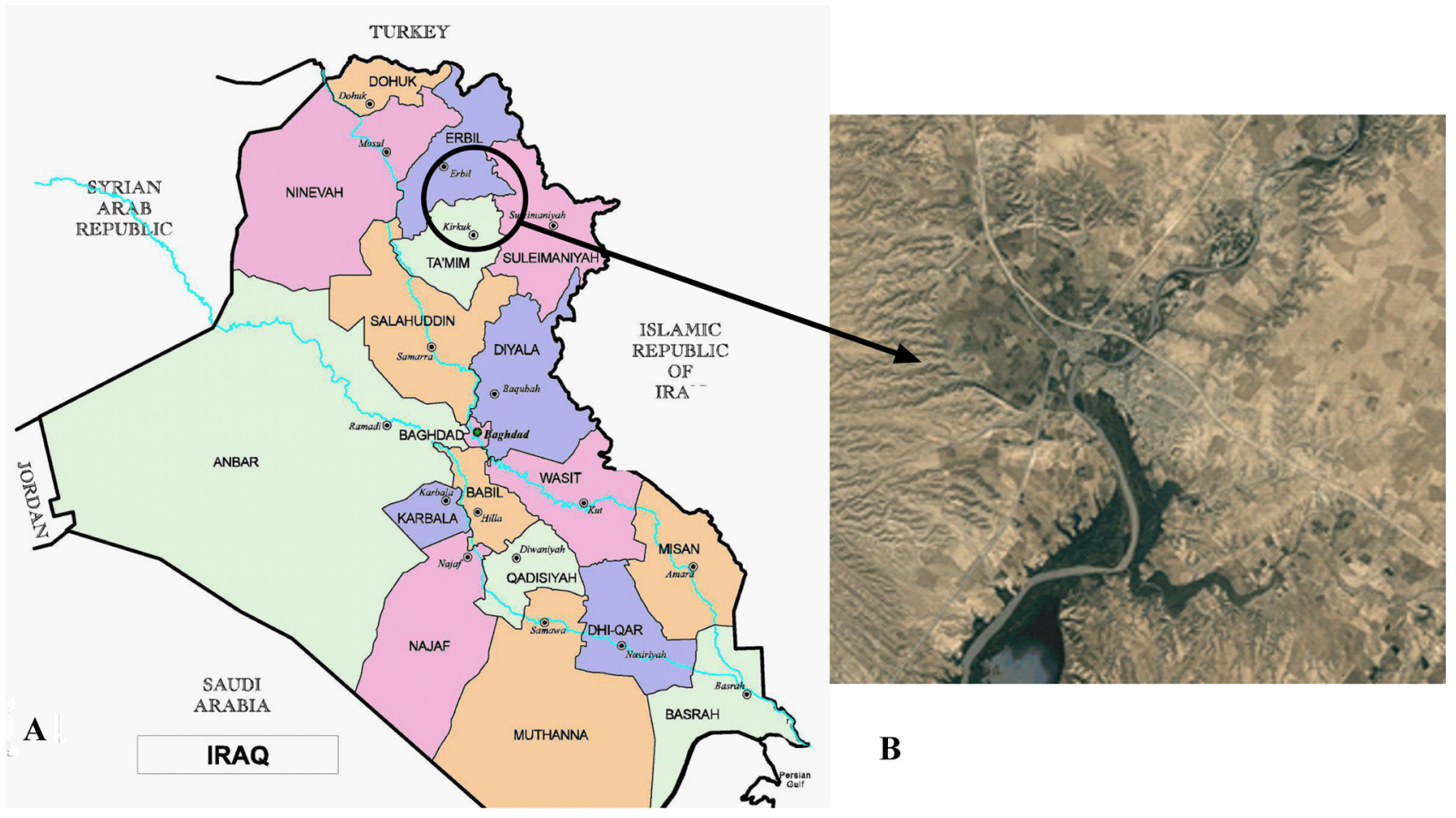

Fig. 1. A- Map of Iraq showing the Northern part. B- Sample collection study area, showing Lesser Zab River at Altun-Kopru. 
(Cyprinidae family) in accordance with Coad [2], and the scientific names followed those provided in FishBase [10], based on the measures in the laboratory for total length (TL), standard length (SL), and body depth (in $\mathrm{cm}$ ), as well as weight in grams (ranging from 5-950 g). Also, males and females of each fish species were differentiated into Acanthobrama marmid, Alburnus mossulensis, Arabibarbus grypus, Barbus (B.) sharpey, B. xanthopterus, Capoeta (C.) damascina, C. trutta, C. umbla, Carasobarbus luteus, Carassus (C.) auratus, C. carassus, Cyprinion macrostomum, Chondrostoma regium, Cyprinus carpio, Gara variablis, Leuciscus vorax, Luciobarbus (L.) esocinus and L. kersin..

\section{Parasitological Examination}

Gills were placed in a Petri dish and left and right arches were each numbered I to IV (I closest to the operculum), and depending on the sides of the head for distribution of Dactylogyrids only a small amount of water was added to the gills. Needle tired parts of gill filaments. At least five living Dactylogyrids were isolated from the water by a small dropper and put individually on a slide with a small drop of water. A piece of melted glycerin-gelatin was dropped with coverslip onto them for clearing the specimens. The coverslip was dried carefully with blotting paper, and they were cautiously thickened in glycerin-gelatin [11] as temporary preparations following Lari et al. [12]. The range and location of Dactylogyrid species on the gill arches were determined using a stereo- and a light microscope and their measurement was used as suggested by Jarkovskỳ et al. [13]. Additionally, they were recognised by detecting the hard components of the haptor and reproductive organs. The isolated species were identified based on their morphology according to Pugachev et al. [14].

\section{Criteria for Infection}

Prevalence, species richness, community species richness, abundance, community abundance, mean intensity, biodiversity indices and host specificity of the parasites participating in the community components (CCs) were investigated depending on $[15,16]$.

\section{Photos and Measurements}

A Sony Xperia Digital Camera model Z 2.0 with 21Mega Pixels was used for taking photos. The figures were taken using a Camera Lucida. Dimensions of Dactylogyrid species were measured with an ocularstage micrometre and Image-J software program.

\section{Statistical Analysis}

The significance of difference among prevalence values was calculated by employing the Chi-squared test. Distribution of Dactylogyrid CC differences were analysed statistically using Tukey's multiple comparision two-way ANOVA and Mann-Whiteney U. All nonparametric data were transformed into natural logarithm (ln) and then analysed and calculated using the SPSS program (version 21.0) and GraphPad-Prism (version 6). References were justified according to the EndNote X7 program.

\section{Results and Discussion}

\section{Host Specificity and Dactylogyrid Species Distribution}

The results of the current study showed the existence of 21 monogeneans Dactylogyrid species parasitising 18 cyprinid fish species in the Lesser Zab River.

Table 1 represents data on the prevalence, individual and mean parasitic community species richness, mean intensities, community and mean community abundance and specificity of the fish hosts for different Dactylogyrid species. Host range varies from one host described as specialists, in which 10 species of Dactylogyrids were detected. While two to three hosts were described as generalists where 11 species were recognised.

The most widespread species was D. pavlovskyi (44.44\%) in Arabibarbus grypus, while the lowest infection rate was recorded with $D$. achmerowi $(1.96 \%)$ in Cyprinus carpio. Statistical analysis showed highly significant differences $(<0.0001)$ for both mean parasite community species richness and community abundance. The maximum mean parasite community species richness was with D. kersini (646), whereas the minimum value (4) was reported for D. achmerowi, $D$. pulcher and D. rectotrabus. Pursuant to mean intensities, the highest value was with $D$. carassobarbi in Carasobarbus luteus (48.62) and mean community abundance was 15.77 for $D$. deziensioides.

As shown in Fig. 2 (a-c), statistically there were no significant differences between mean community species richness (in $\mathrm{ln}$ ), infected host total length $(\mathrm{cm}$ in $\mathrm{ln}$ ), infected host weight ( $\mathrm{gm}$ in $\mathrm{ln}$ ) and specificity of the fish. Oppositely, a significant negative relationship among infected host weight (gm in $\mathrm{ln}$ ) was found for both specialists and generalists $(p<0.0001)$, while infected host total length and parasite community species richness were non-significantly correlated with host specificity.

Concerning fish sample size, individual parasite species richness (in ln) statistically showed no significant correlation ( $\left.\mathrm{p}=0.8091, \mathrm{r}=-0.04372, \mathrm{R}^{2}=0.001912\right)$. At the same time, the correlation between community abundance (in $\ln )$ for both generalists $(\mathrm{p}=0.4601$, $\left.\mathrm{r}=0.1666, \mathrm{R}^{2}=0.02759\right)$ and specialists $(\mathrm{p}=0.3759$, $\mathrm{r}=-0.2966, \mathrm{R}^{2}=0.08799$ ) and fish sample size (in $\mathrm{ln}$ ) were non-significant (Fig. 3a-c).

A recent survey emphasised the specificity patterns of Dactylogyrids attacking the gills of cyprinid fish 


\begin{tabular}{|c|c|c|c|c|c|c|c|c|c|c|c|c|c|c|c|c|c|c|c|}
\hline 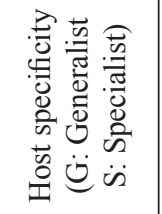 & ט & $\infty$ & ט & ט & ט & ט & $\infty$ & ט & $\infty$ & $\infty$ & $\infty$ & ט & ט & $\infty$ & $\infty$ & $\infty$ & ט & $\infty$ & a \\
\hline 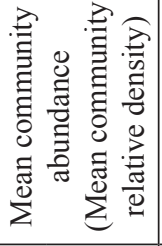 & है & $\stackrel{\infty}{+}$ & 今. & $\stackrel{0}{i}$ & ָิ & $\begin{array}{l}\hat{\text { a }} \\
\text { i }\end{array}$ & $\stackrel{\text { İ }}{\mathrm{i}}$ & $\stackrel{\infty}{\circ}$ & $\stackrel{\infty}{\circ}$ & $\bar{a}$ & $\overline{0}$ & $\ddot{n}$ & 志 & $\stackrel{n}{n}$ & $\stackrel{\infty}{\circ}$ & $\begin{array}{l}\stackrel{0}{0} \\
\vdots\end{array}$ & F. & $\begin{array}{l}\text { ते } \\
\stackrel{\Xi}{*}\end{array}$ & ते \\
\hline 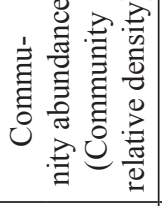 & $\begin{array}{ll}0 & 0 \\
0 & 0 \\
0 & 0 \\
0 & 0\end{array}$ & $\stackrel{\infty}{+}$ & $\begin{array}{cc}\text { mot } \\
\hat{0} & 0 \\
0 & 0 \\
0 & 0\end{array}$ & 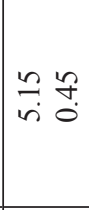 & 悹 ָ̣ f & 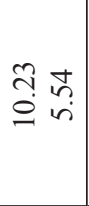 & $\stackrel{\text { ปิ }}{\text { ปั. }}$ & $\begin{array}{l}\hat{F} \\
\dot{0} \\
\dot{0}\end{array}$ & $\stackrel{\infty}{\circ}$ & $\bar{a}$ & $\vec{m}$ & $\stackrel{\infty}{\stackrel{\infty}{m}} \vec{m}$ & 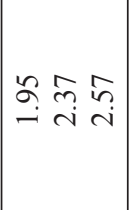 & $\stackrel{n}{n}$ & $\stackrel{\infty}{\circ}$ & $\begin{array}{l}0 \\
\stackrel{0}{0}\end{array}$ & กُ & $\begin{array}{l}\text { సे } \\
\stackrel{\Xi}{ \pm}\end{array}$ & तิ \\
\hline 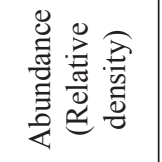 & $\begin{array}{c}\text { के. } \\
0 \\
0 \\
0\end{array}$ & $\stackrel{\infty}{+}$ & चै त़ & $\stackrel{\substack{n \\
i}}{i}$ & $\begin{array}{ll}\infty & 0 \\
& q \\
\sigma & =\end{array}$ & 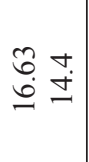 & $\stackrel{\text { fิ }}{\mathrm{i}}$ & $\underset{\ddots}{\rightarrow} \tilde{\sigma}$ & $\stackrel{\infty}{\circ}$ & $\bar{a}$ & $\overrightarrow{3}$ & $\vec{n} \stackrel{\simeq}{=}$ & 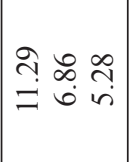 & $\stackrel{n}{n}$ & $\stackrel{\infty}{\circ}$ & $\begin{array}{l}0 \\
\stackrel{0}{0}\end{array}$ & 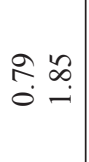 & $\begin{array}{l}\text { ते } \\
\dot{\Xi}\end{array}$ & ते \\
\hline 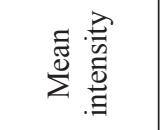 & $N \sim$ & 0 & $\stackrel{n}{-} N$ & $\stackrel{a}{a} \pm$ & 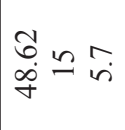 & $\infty \underset{m}{\infty}$ & $\because$ & 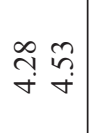 & $m$ & กู & $\nabla$ & $\cong i$ & 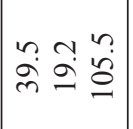 & $\begin{array}{l}\stackrel{+}{\infty} \\
\stackrel{\infty}{\sigma}\end{array}$ & $\ddot{n}$ & $\because$ & 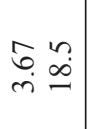 & $N$ & $\stackrel{m}{?}$ \\
\hline 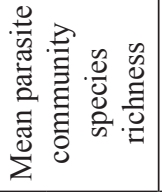 & $\checkmark$ & $\stackrel{\infty}{+}$ & r & $\stackrel{\Omega}{I}$ & $\tilde{\sim}$ & 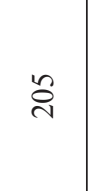 & $\stackrel{2}{\beth}$ & $\stackrel{n}{\varrho}$ & 0 & n & 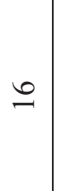 & 孛 & $\infty$ & $\underset{\sim}{ \pm}$ & $\tilde{\infty}$ & $\stackrel{\infty}{\sim}$ & $\stackrel{\infty}{+}$ & $\nabla$ & $\nabla$ \\
\hline 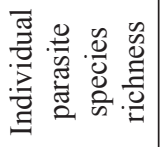 & $\nabla \nabla$ & $\stackrel{\infty}{+}$ & $0 \infty$ & $\frac{\infty}{m} \stackrel{\infty}{\sim}$ & तై & 过 & $\stackrel{0}{\mathbb{I}}$ & $\Xi \infty$ & 0 & n & 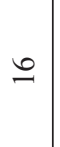 & $\underset{\infty}{\infty} \cong$ & $\stackrel{\infty}{\curvearrowleft} \stackrel{\sim}{\sim} \bar{\sim}$ & $\underset{\infty}{ \pm}$ & $\infty$ & $\infty$ & สำ & t & $\nabla$ \\
\hline 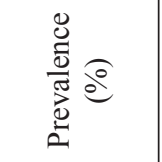 & 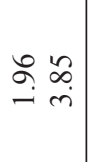 & $\infty$ & $\stackrel{i}{i}=$ & $\hat{i} \dot{i}$ & 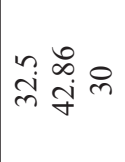 & $\stackrel{\substack{c \\
\dot{q}}}{q}$ & $\stackrel{\infty}{\stackrel{\infty}{i}}$ & $\begin{array}{l}\vec{\sim} \\
\stackrel{\sim}{\sim} \\
\stackrel{\sim}{\sim}\end{array}$ & $\grave{i}$ & 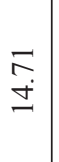 & $\stackrel{a}{i}$ & $\stackrel{n}{m} \pi$ & 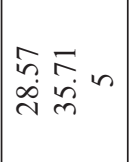 & $\stackrel{\infty}{\circ}$ & $\tilde{\check{r}}$ & $\begin{array}{l}\stackrel{f}{+} \\
\dot{f}\end{array}$ & 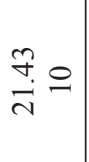 & $\begin{array}{l}\infty \\
m \\
n \\
n\end{array}$ & $\stackrel{n}{m}$ \\
\hline 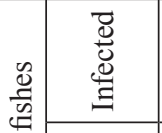 & $N N$ & $\infty$ & $\nabla \sigma$ & $\stackrel{0}{2}$ & $\begin{array}{lll}2 & 0 & 0\end{array}$ & $r+$ & $\simeq$ & q & N & $\because$ & $\nabla$ & ON & $\nabla \odot N$ & 으 & 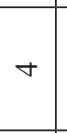 & $\nabla$ & $0 ナ$ & $N$ & $m$ \\
\hline 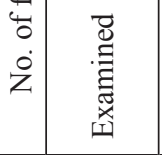 & $\tilde{\sigma} \approx$ & 은 & 守 & in 0 & 오 & $ㅇ ㅡ$ & in & 牙栗 & $\frac{1}{4}$ & ฮै & กิ & 으으 & $\pm \underset{\sim}{\infty}$ ㅇ & ฮै & ฮิ & $a$ & $\stackrel{\sim}{\sim}$ 우 & \pm & $\infty$ \\
\hline 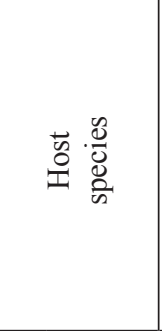 & 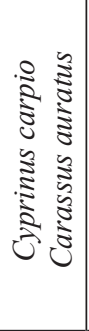 & 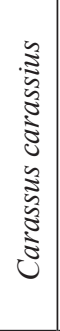 & 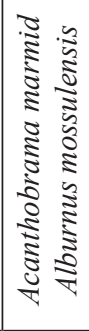 & 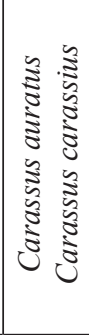 & 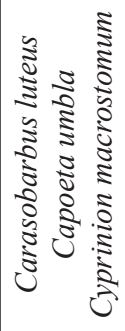 & 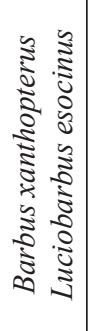 & 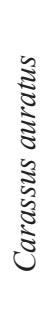 & 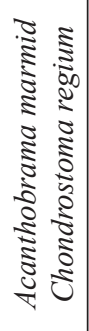 & 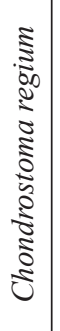 & 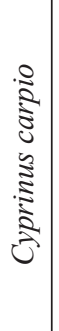 & 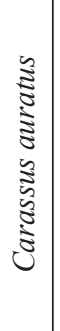 & 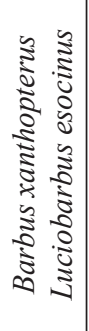 & 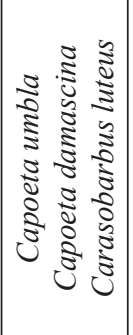 & 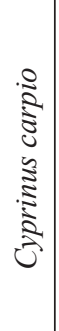 & 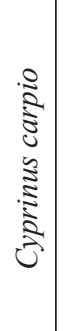 & 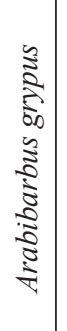 & 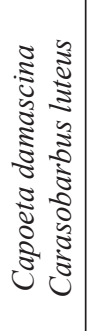 & 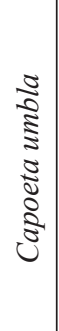 & $\begin{array}{l}0 \\
0 \\
0 \\
0 \\
0 \\
0 \\
0 \\
0\end{array}$ \\
\hline 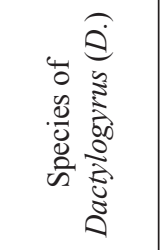 & 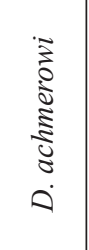 & 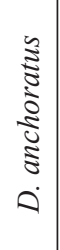 & $\begin{array}{l}3 \\
\frac{3}{8} \\
0 \\
0\end{array}$ & 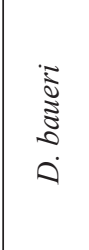 & $\begin{array}{l}\overline{0} \\
\overline{0} \\
0 \\
0 \\
\overline{0} \\
0 \\
0\end{array}$ & 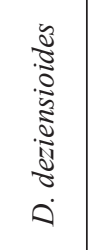 & 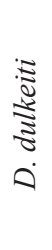 & 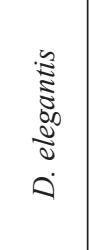 & $\begin{array}{l}5 \\
\overline{5} \\
0 \\
0 \\
0\end{array}$ & 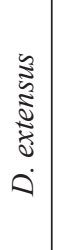 & 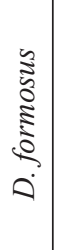 & 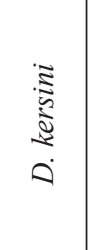 & $\frac{0}{0}$ & 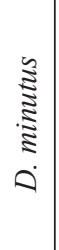 & $\begin{array}{c}0 \\
\vdots \\
\vdots \\
0 \\
\vdots \\
0\end{array}$ & $\begin{array}{c}\tilde{3} \\
0 \\
0 \\
0 \\
\vdots \\
\vdots \\
\vdots \\
0\end{array}$ & 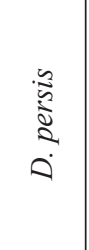 & 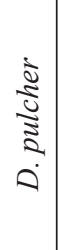 & 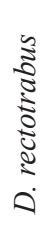 \\
\hline
\end{tabular}




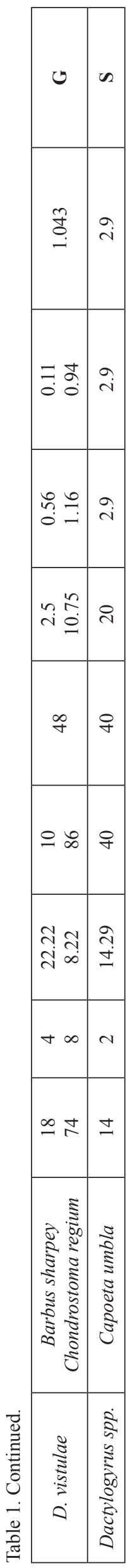

elaborately. So far, the previous literature has described 82 monogenean species in wild and artificially cultured freshwater fish of Iraq. Among them, 47 species were Dactylogyrids, which had been detected in the north of the country [7]. Host specificity is one of the fundamental biological impacts affecting the diversity and life cycle of parasites [17]. Monogeneans are taken into consideration for exceptional host specifics regarding infectivity assessment of different groups of fish parasites [18]. Having said the environmental adaptation and host-specifics had limited the effect on their distribution [19]. In contrast, many monogenean species exhibit a high degree of specificity. Consequently, parasite variation in one host species could explain the attachment organ morphology [13].

Furthermore, Dactylogyrid species are distinctly host-specific, generally infecting one or several congeneric hosts. As stated above, the former is classified as specialists, while the latter as generalists [20]. In light of the present study results, D. anchoratus,

a)

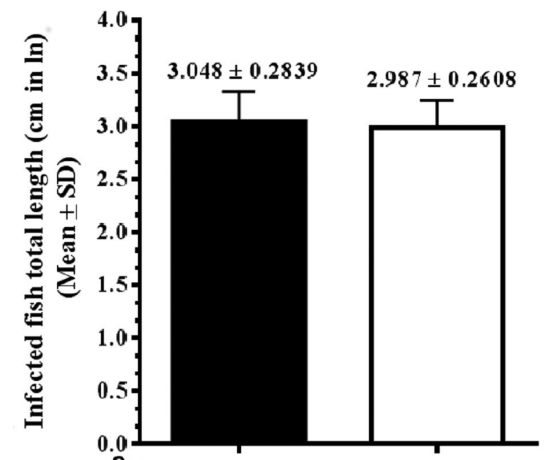

b)

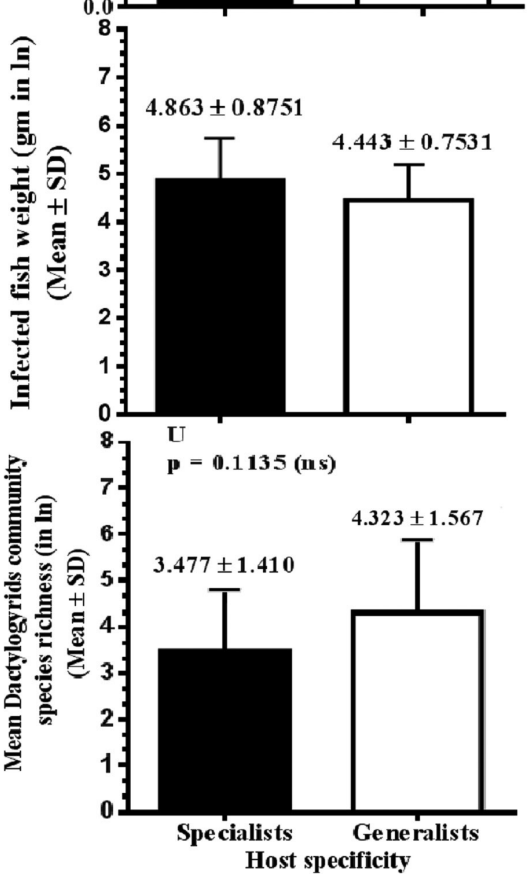

Fig. 2. Differences between: a) Infected fish total length ( $\mathrm{cm}$ in ln) and host specificity (specialists versus generalists). b) Infected fish weight (gm in $\mathrm{ln}$ ) and host specificity (specialists versus generalists). c) Mean Dactylogyrids community species richness (in ln) and host specificity (specialists versus generalists). 
a)

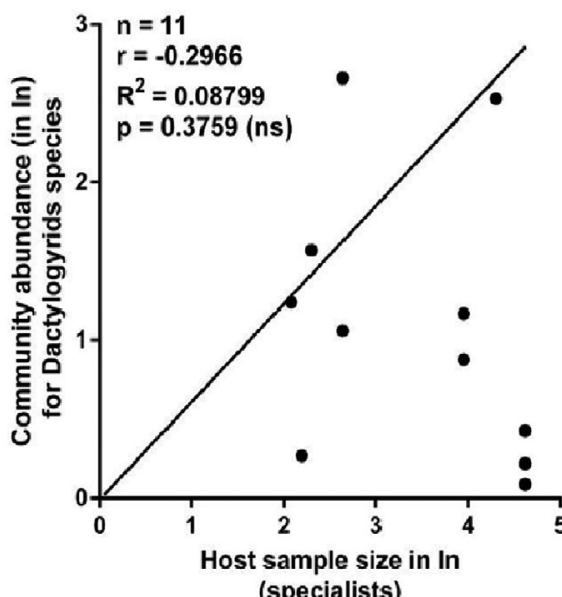

b)

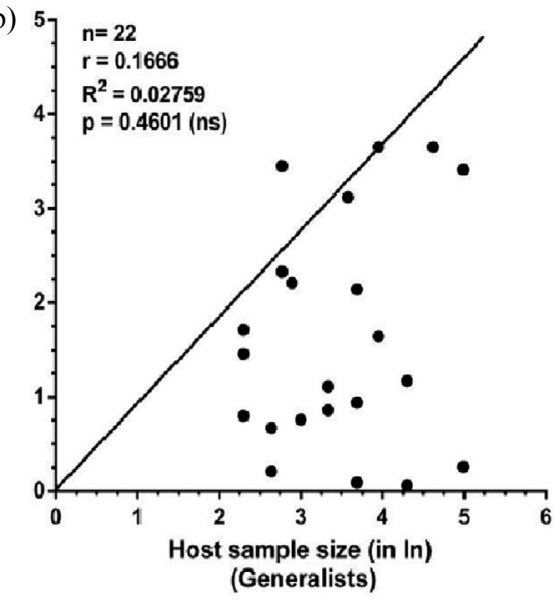

c)

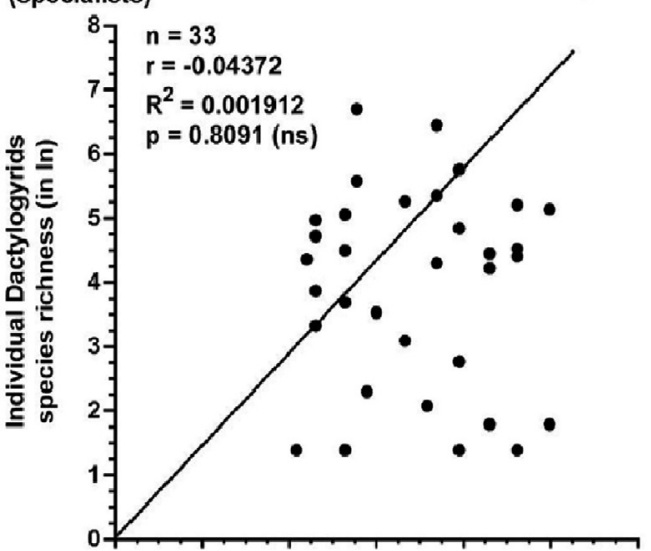

Fig. 3. Relationships between a) Community abundance (in ln) and host sample size (in ln) (specialists). b) Community abundance (in ln) and host sample size (in ln) (generalists). c) Individual Dactylogyrids species richness (in $\ln$ ) and host sample size (in ln).

D. alatus and D. vistulae, isolated from two species of cyprinid fish, are considered as generalists. On the other hand, D. dulkeiti, D. ergensi, D. extensus and $D$. formosus were reported on a single fish host species and deemed as specialists; these findings agree with the conclusions of Jarkovskỳ et al. [13].

Concerning the distribution of parasites, it was confirmed that neither abundance nor prevalence was affected by the parasite-host specificity [21]. However, generalists manipulating several host species would possibly acquire a lesser mean abundance in their hosts than specialists infesting a small number of hosts [22]. The positive correlation between rampancy and abundance was found for both generalists and specialists. Nevertheless, generalists were observed to be further widely distributed among hosts and had better abundances than specialists [23].

According to the outcomes of a study, positive relationships between monogenean species richness and fish body length have been formerly suggested. It may be argued that the largest fish are most enormous and most permanent targets for parasitic colonisation [21]. Due to the presence of slight variations among species of Dactylogyrids, it is not easy to distinguish between them. Generally, the identification of these species relies upon accurate descriptions of the opisthaptor and copulatory complex [24, 25].
It has been acclaimed that high parasite species variety may be an indication of individual fish growth and body condition. Additionally, relationships among abundance, the richness of parasites and fish body size have generally been pointed out in investigations of components (CCs) [26-28]. The monogenean effect on wild fish populations is generally negligible. A study stated that low densities of monogeneans commonly occur in wild fish populations, and in apparent stability with their hosts [29].

\section{Fish sex and Morphometrics about Dactylogyrid Species Communities}

Real Dactylogyrid communities ranged 2-4 species based on the data of sex, weight and length of 18 collected fish species as summarised in Table 2. There were non-significant differences in species richness or mean abundance of collected Dactylogyrids between each male and female fish species $(\mathrm{P}>0.05)$.

It has been suggested that some intraspecific morphological factors in both sexes of some species have essential impacts on their occupation and survival in a particular habitat type [30]. Many factors can affect the CCs of the fish parasite fauna, such as food, host sex, physical and chemical parameters of water [31, 32]. 
The fish of both sexes with similar morphology and feeding habits may additionally provide evidence of the similarity of the infection with parasites [33]. However, some researchers have given examples on the presence of differences between them, for instance higher infection in females than males reported by Richards et al. [34]. The same authors later reported this as higher in males than females [35]. The results of the present study did not observe any differences between the sexes of fish. In this regard, the current conclusions do not differ from the extracted results of some studies, which revealed the absence of any distinction in the infestation of both sexes with most monogenean parasites [31,36]. This finding also confirms the observations noted on $D$. minutus of Cyprinus carpio [37], and D. rectotrabus of Garra rufa in the Lesser and Greater Zab Rivers of Iraq [38].

This study demonstrated that sex of fish did not influence the outbreak and intensity of Dactylogyrid

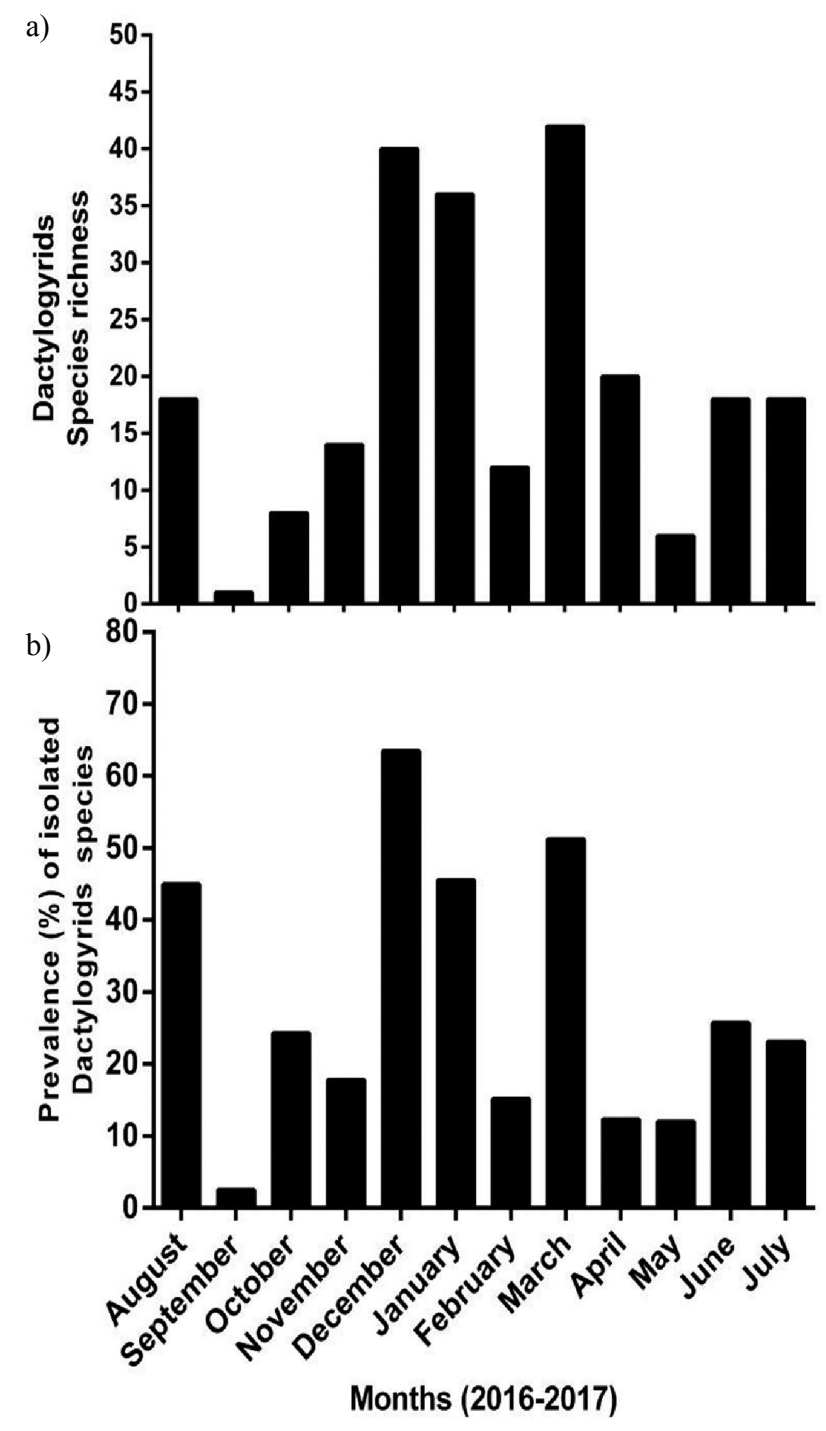

Fig. 4. Isolated Dactylogyrids species on the fishes according to months of the study (August 2016 - July 2017). a) Species richness of Dactylogyrids species. b) Prevalence of Dactylogyrids species. species. On the other hand, significant differences in the frequency of some Dactylogyrid species between both sexes, in which females were more severely parasitised than males, have found by Özer and Öztürk [39].

\section{Dactylogyrids Species Monthly Dynamics}

The most occurring species along the entire period of the study was with $D$. elegantis. The highest species richness (42) was reported in March 2017, whereas the lowest was one and reported in September 2017 (Fig. 4a). On the other hand, the highest prevalence of Dactylogyrid species which was above $50 \%$ of infection was reported in December 2016 and March 2017 with a rate of $63.49 \%$ and $51.22 \%$, respectively, while the lowest rate of infection (2.5\%) occurred in September 2016 (Fig. 4b).

The Shannon diversity index and species evenness of Dactylogyrids were calculated for examined fish in different months of the study as represented in Fig. 5, in which the highest diversity index and species evenness were reported for January 2017.

Investigations about monthly dynamics of Dactylogyrid species is essential regarding the understanding of their biology and to prevent possible problems that might occur during infection [40]. Unfavourable conditions throughout winter months might increase the sensitivity of the host to larval parasites and result in higher mean intensities [41]. A higher rate of fish susceptibility in the dry season may result in relatively higher parasite intensities [42]. Since the situations lead to lower oxygen accessibility with higher fish masses, in some instances higher mortality will occur [43]. In the inlet stream, water availability is tremendously reduced throughout the dry season, and land barriers isolate sections of the stream, which conduce to concentrations of monogeneans.

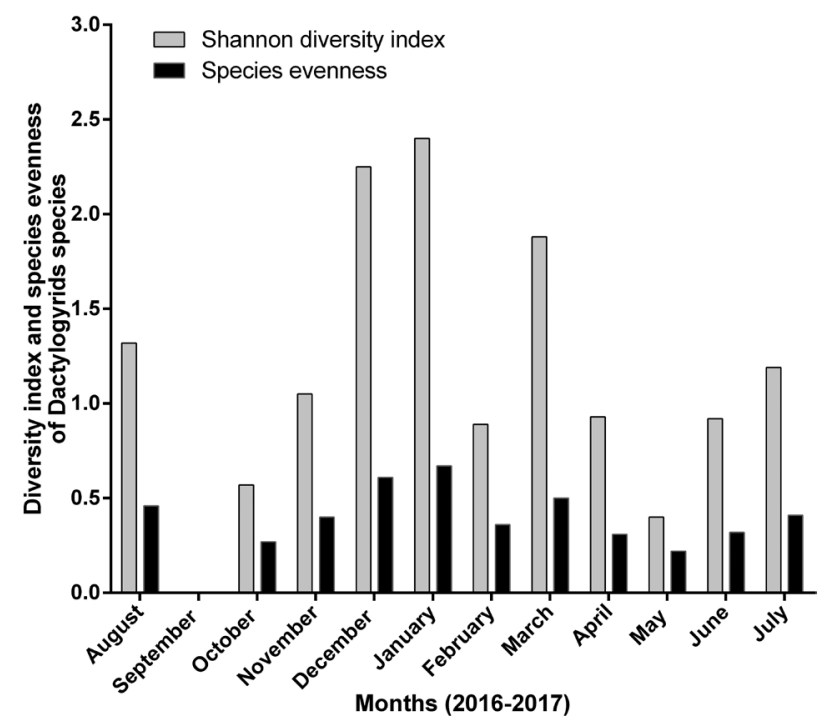

Fig. 5. Shannon diversity index and species evenness of isolated Dactylogyrids species on the fishes according to months of the study (August 2016 - July 2017). 


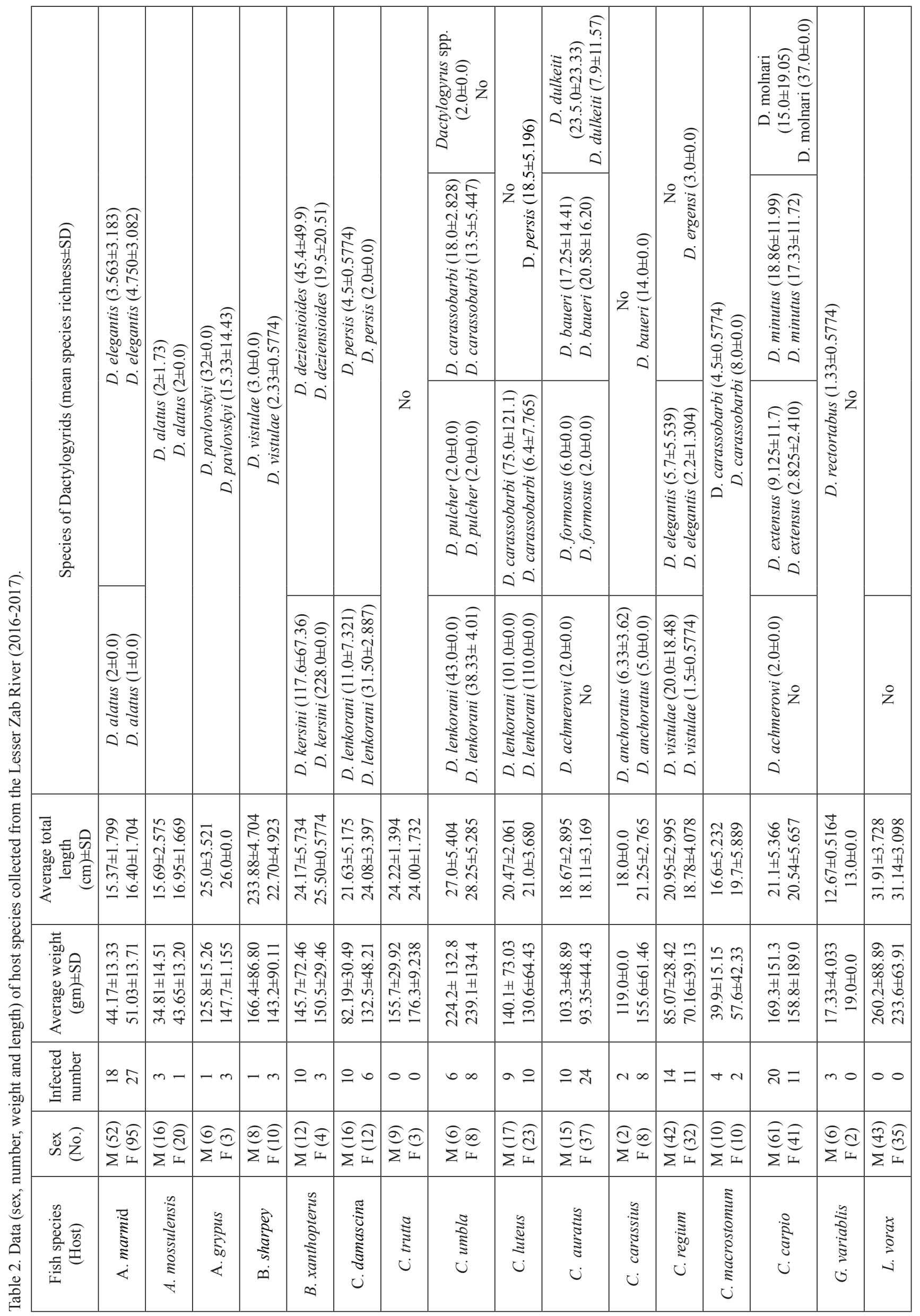




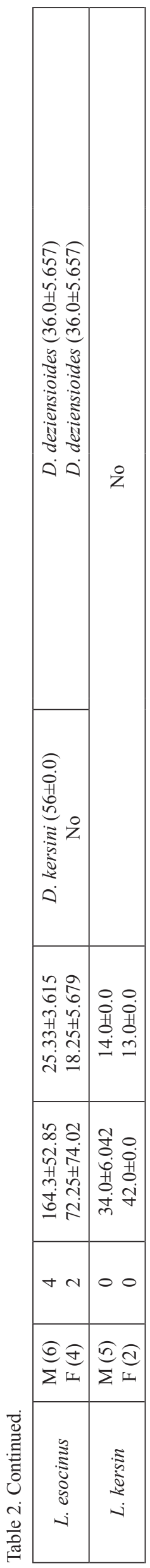

In a study carried out in Iran, the infection rate with Dactylogyrids was significantly different in four seasons, but there were non-significant differences between fish that had disimmilar weights and lengths [44]. Having said that, the study above observations concur with the outcomes of the present study. Species diversity, as traditionally defined by ecologists, has two components that should be captured by any index: richness and evenness [45]. The highest Shannon's diversity index (SDI) and species evenness were reported from January 2017. Overall, the monthly changes of all indices for the parasite species disagreed with that reported by Kadlec et al. [46]. They stated that SDI had reached the highest values in autumn, while species evenness was highest in spring and autumn.

The parasite CCs of fish is an indicator of aquatic environmental changes [46]. As proposed that the use of diversity indices could be helpful in measuring environmental stress because this alters biotic diversity and species dominance [47]. For instance, the highest species richness at the CCs level was observed in spring, and the highest SDI was found in winter.

\section{Community Components of Dactylogyrid Species}

The structure community of Dactylogyrids according to gill arch numbers and sides to the head are summarised in Fig. 6 and Table 3. Overall, the highest CCs of Dactylogyrids according to fish species were reported for the left gill arch set, except for the species Arabibarbus grypus, Barbus xanthopterus, Capoeta luteus and Luciobarbus esocinus, but statistically there were non-significant differences for both gill set sides. The highest total abundance was in gill numbers II and III from the left and right sides (630 and 624 respectively). Tukey's multiple comparison two-way ANOVA for the distribution of Dactylogyrid CCs statistically did not have significant differences among the left gill arch set $(\mathrm{p}>0.5)$ for all the mentioned studied fish species, whereas within the right gill arch numbers II and III were significantly different with the gill arch IV $(p<0.05$ and $p<0.01$ respectively). While for the same side, gill arch number III had highly significant $(\mathrm{p}<0.01)$ differences with gill arch IV. The statistical differences for a different sets of gill arches were reported only for right gill arch IV in comparison to the left gill arches II and III $(\mathrm{p}>0.05)$.

CCs of each Dactylogyrids among left and right sides were significantly highly correlated (Spearman $\mathrm{r}=0.9365, \mathrm{p}<0.0001)$, but the differences were insignificant (Mann Whitney $U, p=0.7434$ ) for both gill sides.

Micro-environmental specificity is common among monogeneans, and it has effects in numerous ways. There may be a limitation to particular gill arches, specific parts, outside or inside right or left gills and filaments [48]. According to the results of a study, further parasites are accumulated on gill arch number 


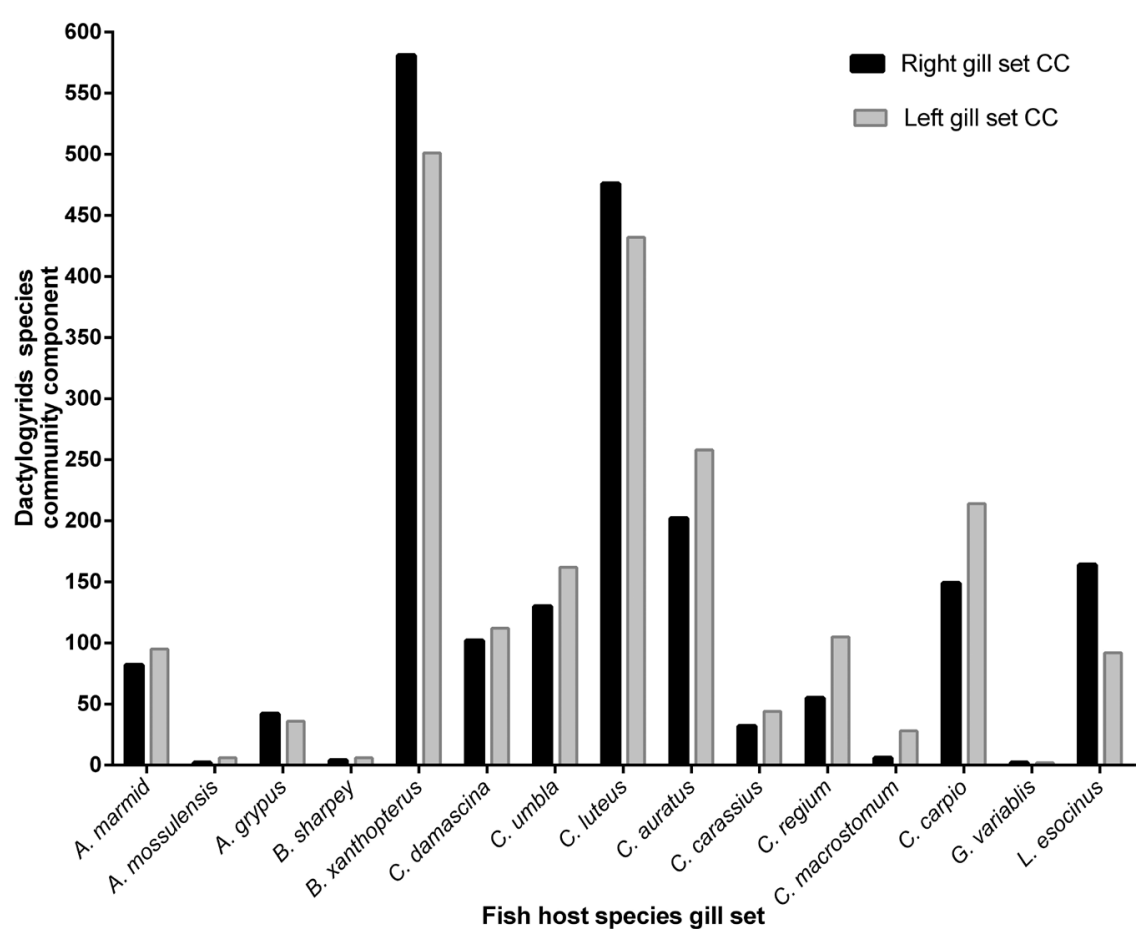

Fig. 6. Gill arches of different fish hosts about Dactylogyrids species community components (CCs).

Table 3. Infection statistics for Dactylogyrid species collected from 15 fish species during August 2016 to September 2017.

\begin{tabular}{|c|c|c|c|c|c|c|c|c|c|c|}
\hline \multirow[t]{2}{*}{ Fish species (Host) } & \multirow{2}{*}{$\begin{array}{l}\text { Dactylogyrids species } \\
\text { Community Components } \\
\text { (CCs) }\end{array}$} & \multicolumn{4}{|c|}{$\begin{array}{l}\text { Right (head side) } \\
\text { gill arch number }\end{array}$} & \multicolumn{4}{|c|}{$\begin{array}{c}\text { Left (head side) gill arch } \\
\text { number }\end{array}$} & \multirow{2}{*}{$\begin{array}{c}\text { Intensity } \\
\text { range }\end{array}$} \\
\hline & & I & II & III & IV & I & II & III & IV & \\
\hline \multirow{3}{*}{ A. marmid } & D. alatus & 0 & 2 & 0 & 2 & 0 & 0 & 2 & 0 & $0-2$ \\
\hline & D. elegantis & 17 & 19 & 25 & 17 & 16 & 28 & 33 & 16 & $0-6$ \\
\hline & $\mathrm{CCs}$ & 17 & 21 & 25 & 19 & 16 & 28 & 35 & 16 & \\
\hline \multirow{2}{*}{ A. mossulensis } & D. alatus & 0 & 0 & 2 & 0 & 2 & 4 & 0 & 0 & $0-2$ \\
\hline & $\mathrm{CCs}$ & $\mathbf{0}$ & $\mathbf{0}$ & 2 & $\mathbf{0}$ & 2 & 4 & $\mathbf{0}$ & $\mathbf{0}$ & \\
\hline \multirow{2}{*}{ A. grypus } & D. pavlovskyi & 6 & 12 & 14 & 10 & 8 & 14 & 6 & 8 & $0-7$ \\
\hline & $\mathrm{CCs}$ & 6 & 12 & 14 & 10 & 8 & 14 & 6 & 8 & \\
\hline \multirow{2}{*}{ B. sharpey } & D. vistulae & 2 & 2 & 0 & 0 & 4 & 2 & 0 & 0 & $0-1$ \\
\hline & $\mathrm{CCs}$ & 2 & 2 & 0 & $\mathbf{0}$ & 4 & 2 & 0 & 0 & \\
\hline \multirow{3}{*}{ B. xanthopterus } & D. kersini & 120 & 118 & 126 & 76 & 54 & 102 & 112 & 108 & $2-42$ \\
\hline & D. deziensioides & 41 & 28 & 49 & 23 & 22 & 36 & 28 & 39 & $0-15$ \\
\hline & $\mathrm{CCs}$ & 161 & 146 & 175 & 99 & 76 & 138 & 140 & 147 & \\
\hline \multirow{3}{*}{ D. damascina } & D. lenkorani & 34 & 24 & 16 & 16 & 26 & 30 & 30 & 16 & $0-9$ \\
\hline & D. persis & 8 & 2 & 2 & 0 & 6 & 2 & 2 & 0 & $0-2$ \\
\hline & $\mathrm{CCs}$ & 42 & 26 & 18 & 16 & 32 & 32 & 32 & 16 & \\
\hline \multirow{5}{*}{ C. umbla } & D. carassobarbi & 0 & 4 & 20 & 6 & 8 & 12 & 28 & 12 & $0-10$ \\
\hline & D. lenkorani & 22 & 32 & 12 & 14 & 10 & 36 & 20 & 12 & $2-12$ \\
\hline & D. pulcher & 0 & 2 & 2 & 0 & 0 & 0 & 0 & 0 & $0-1$ \\
\hline & Dactylogyrus spp. & 0 & 0 & 14 & 2 & 0 & 4 & 20 & 0 & $0-10$ \\
\hline & $\mathrm{CCs}$ & 22 & 38 & 48 & 22 & 18 & 52 & 68 & 24 & \\
\hline
\end{tabular}


Table 3. Continued.

\begin{tabular}{|c|c|c|c|c|c|c|c|c|c|c|}
\hline \multirow{4}{*}{ C. luteus } & D. carassobarbi & 77 & 83 & 122 & 20 & 80 & 122 & 91 & 37 & $0-57$ \\
\hline & D. lenkorani & 48 & 36 & 34 & 12 & 26 & 14 & 20 & 12 & $6-24$ \\
\hline & D. persis & 6 & 12 & 14 & 12 & 8 & 10 & 6 & 6 & $1-5$ \\
\hline & $\mathrm{CCs}$ & 131 & 131 & 170 & 44 & 114 & 146 & 117 & 55 & \\
\hline \multirow{5}{*}{ C. auratus } & D. achmerowi & 0 & 0 & 0 & 0 & 2 & 2 & 0 & 0 & $0-1$ \\
\hline & D. baueri & 38 & 64 & 34 & 28 & 52 & 52 & 32 & 14 & $0-12$ \\
\hline & D. dulkeiti & 10 & 2 & 12 & 2 & 36 & 24 & 28 & 12 & $0-12$ \\
\hline & D. formosus & 0 & 10 & 2 & 0 & 0 & 2 & 2 & 0 & $0-3$ \\
\hline & CCs & 48 & 76 & 48 & 30 & 90 & 80 & 62 & 26 & \\
\hline \multirow{3}{*}{ C. carassius } & D. anchoratus & 0 & 12 & 6 & 2 & 4 & 10 & 10 & 4 & $0-3$ \\
\hline & D. baueri & 6 & 0 & 6 & 0 & 8 & 0 & 0 & 8 & $0-4$ \\
\hline & CCs & 6 & 12 & 12 & 2 & 12 & 10 & 10 & 12 & \\
\hline \multirow{4}{*}{ C. regium } & D. vistulae & 4 & 8 & 2 & 0 & 6 & 4 & 62 & 0 & $0-31$ \\
\hline & D. elegantis & 16 & 11 & 8 & 4 & 18 & 5 & 2 & 4 & $0-3$ \\
\hline & D. ergensi & 0 & 0 & 2 & 0 & 4 & 0 & 0 & 0 & $0-2$ \\
\hline & $\mathrm{CCs}$ & 20 & 19 & 12 & 4 & 28 & 9 & 64 & 4 & \\
\hline \multirow{2}{*}{ C. macrostomum } & D. carassobarbi & 0 & 4 & 2 & 0 & 0 & 20 & 8 & 0 & $0-4$ \\
\hline & $\mathrm{CCs}$ & $\mathbf{0}$ & 4 & 2 & $\mathbf{0}$ & $\mathbf{0}$ & 20 & 8 & $\mathbf{0}$ & \\
\hline \multirow{5}{*}{ C. carpio } & D. achmerowi & 0 & 4 & 0 & 0 & 0 & 0 & 0 & 0 & $0-2$ \\
\hline & D. extensus & 17 & 16 & 6 & 6 & 10 & 21 & 6 & 11 & $0-7$ \\
\hline & D. minutus & 20 & 10 & 18 & 20 & 26 & 40 & 22 & 28 & $0-11$ \\
\hline & D. molnari & 0 & 0 & 18 & 14 & 6 & 12 & 10 & 22 & $0-9$ \\
\hline & $\mathrm{CCs}$ & 37 & 30 & 42 & 40 & 42 & 73 & 38 & 61 & \\
\hline \multirow{2}{*}{ G. variablis } & D. rectortabus & 0 & 2 & 0 & 0 & 1 & 0 & 1 & 0 & $0-1$ \\
\hline & CCs & $\mathbf{0}$ & 2 & $\mathbf{0}$ & $\mathbf{0}$ & 1 & $\mathbf{0}$ & 1 & $\mathbf{0}$ & \\
\hline \multirow{3}{*}{ L. esocinus } & D. kersini & 24 & 20 & 14 & 14 & 10 & 4 & 22 & 4 & $2-12$ \\
\hline & D. deziensioides & 22 & 22 & 42 & 6 & 14 & 18 & 10 & 10 & $2-11$ \\
\hline & $\mathrm{CCs}$ & 46 & 42 & 56 & 20 & 24 & 22 & 32 & 14 & \\
\hline
\end{tabular}

I or II preferring both sides of gills. Spatial parasite distribution is supposed to result from water flow over the gills in the course of respiration [41].

Most of the respiratory water flows via the III pair of gill arches and the lesser amounts flow through the II and IV gill pairs [49]. Variations in surface area or water flow among the various components of the gill arches have a critical influences in defining the distribution of the parasite on the gills [50]. Some monogeneans choose gill arches with the lowest water flows, normally I and IV, to keep them away from washing. Conversely, the intermediate two gill arches are frequently the ones with the maximum parasite abundance, thought to be in connection with the surface area and the volume of the water flow, which is in a positive relationship with dissolved oxygen [51]. At the species level, individual parasites were highly accumulated within the filaments, fundamentally showing a strong affinity to occur at either end of a filament to keep away from being removed during locomotion for food [18].

\section{Conclusions}

This study is the first comprehensive survey regarding the diversity and distribution of fish Dactylogyrid species in the Lesser Zab River of Iraq. Eleven recorded species were considered as generalists and 10 as specialists. The most widespread species was with $D$. pavlovskyi, whereas the lowest prevalence was with $D$. achmerowi. Regarding CC levels, the mean parasite community richness was highest with 
D. kersini. A significant negative relationship was reported between infected host weight and host specificity. Otherwise, host total length and the Dactylogyrid community species richness were insignificantly correlated with the host specificity. Species richness and mean abundance in both sexes were the non-significant differences. Regarding the months of the study, the highest species richness was reported in March 2017. The highest Dactylogyrid CCs were reported among $B$. xanthopterus for both right and left gill sides.

\section{Acknowledgements}

The present work was supported by Salahaddin University, College of Science, Biology Department. We are very grateful to all those who assisted us in catching and collecting the fish. The authors would like to thank veterinarian and parasitologist Dr. Kareem K. Hamad from Salahaddin University, and Mr. Younis S. Abdullah from Sulaimani Polytechnic University, College of Technical Health/Medical Laboratory for improvements on an earlier draft of this manuscript.

\section{Conflict of Interest}

The authors declare no conflict of interest.

\section{References}

1. NELSON J.S. Fish of the world. New York, USA: Wiley. 2006.

2. COAD B.W. Freshwater fish of Iraq. Sofia-Moscow: Pensoft. 275, 2010.

3. SIMKOVA A., BENOVICS M., RAHMOUNI I., VUKIC J. Host-specific Dactylogyrus parasites revealing new insights on the historical biogeography of Northwest African and Iberian cyprinid fish. Parasite and Vectors, 10 (1), 589, 2017.

4. ŠIMKOVá A.A., MATEUSOV V.I., CUNNINGHAM C. A molecular phylogeny of the Dactylogyridae sensu Kritsky and Boeger (1989) (Monogenea) based on the D1-D3 domains of large subunit rDNA. Parasitol, 133, 43, 2006.

5. ŜIMKOVá A., MORAND S., JOBET E., GELNAR M., VERNEAU O. Molecular phylogeny of congeneric monogenean parasites (Dactylogyrus): A case of intrahost speciation Evol, 58 (5), 1001, 2004.

6. EL-GHARBI S., RENAUD F., LAMBERT A. Dactylogyrids (Platyhelminthes: Monogenea) of Barbus spp. (Teleostei: Cyprinidae) from the Iberian peninsula. Res Rev Parasitol 52, 103, 1992.

7. MHAISEN F.T., ABDULLAH S.M.A. Parasites of Fish of Kurdistan Region, Iraq: Checklists. Biol Appl Environ Res, 1, 131, 2017.

8. PETROV A., GERASEV P., POPYUK M., DMITRIEVA E. Haptoral neuromusculature in two species of Dactylogyrus Diesing, 1850 (Monogenea: Dactylogyridae). Syst Parasitol, 93 (4), 337, 2016.
9. ABDULLAH S.M.A., NASRADDIN M.O. Monogenean Infections on Some Fish from Lesser Zab River, Kurdistan Region, Iraq. Amer J Biol Life Sci, 3 (5), 161, 2015.

10. FROESE R., PAULY D. FishBase. World web electronic publication (10/2017) 2017.

11. KRITSKY D.C., PANNDEY K.C., AGRAWAL N., ABDULLAH S.M.A. Monogenoids from the gills of spiny eels (Teleostei: Mastacembelidae) in India and Iraq, proposal of Mastacembelocleidus gen. n., and status of the Indian species of Actinocleidus, Urocleidus and Haplocleidus (Monogenoidea: Dactylogyridae) Folia Parasitol, 51, 291, 2004.

12. LARI E., ADAMS R.V., CONE D.K., GOATER C.P., PYLE G.G. Dactylogyrus olfactorius n. sp. (Monogenea, Dactylogyridae) from the olfactory chamber of the fathead minnow, Pimephales promelas Rafinesque (Cyprinidae). Syst Parasitol, 93 (6), 575, 2016.

13. JARKOVSKỲ J., MORAND S., ṠIMKOVá A., GELNAR M. Reproductive barriers between congeneric monogeneans parasites (Dactylogyrus: Monogenea): attachment apparatus morphology or copulatory organ incompatibility. J Parasitol Res, 92, 95, 2004.

14. PUGACHEV O.N., GERASEV P.I., GUSSEV A.V., ERGENS R., KHOTENOWSKY I. Guide to monogenoidea of freshwater fish of Palaeartic and Amur regions. Milano: Ledizioni Ledi publishing. 2010.

15. MARGOLIS L.G., ESCH J., HOLMES J.C., KURIS A.M., SCHAD G.A. The use of ecological terms in parasitology (report of an ad hoc committee of the American Society of Parasitologists). J Parasitol, 68, 131, 1982.

16. BUSH A.O., LAFFERTY K.D., LOTZ J.M., SHOSTAK A.W. Parasitology meets ecology on its own terms: Margolis et al. revisited. J Parasitol, 83, 575, 1997.

17. SCHOELINCK C., CRUAUD C., JUSTINE J.L. Are all species of Pseudorhabdosynochus strictly host specific? A molecular study. Parasitol Inter, 61 (2), 356, 2012.

18. GILBERT B.M., AVENANT-OLDEWAGE A. Seasonal occurrence and microhabitat specificity of Paradiplozoon ichthyoxanthon Avenant-Oldewage in Avenant- Oldewage et al., 2014 (Monogenea: Diplozoidae) infecting Labeobarbus aeneus (Burchell) (Teleostei: Cyprinidae) from the Vaal Dam, South Africa: water quality and host size as determining factors? Folia Parasitol, 63 (004), 1, 2016.

19. PAZOOKI J., GOORABZARMAKHI F.T., MASOUMIAN M. Parasitic Infection of an Endemic Fish (Blicca bjoerkna) and an Exotic Fish (Hemiculter beucisculus) In Anzali Lagoon, Caspian Sea, Iran. Iran J Parasitol, 6 (3), 66, 2011.

20. ŠIMKOVá A., MORAND S. Co-evolutionary patterns in congeneric monogeneans: a review of Dactylogyrus species and their cyprinid hosts. J Fish Biol, 73 (9), 2210, 2008.

21. MORAND S., GUE'GAN J.F. Distribution and Abundance of Parasite Nematodes: Ecological Specialisation, Phylogenetic Constraint or Simply Epidemiology? Oikos, 88 (3), 563, 2000.

22. SHEATH D. Ecological consequences of indigenous and non-indigenous freshwater fish parasites $[\mathrm{PhD}]$. Fern Barrow, Poole, Dorset, BH12 5BB, United Kingdom: Bournemouth University. 292,. 2016.

23. ŠIMKOVÁ A., KADLEC D., GELNAR M., MORAND S. Abundance - prevalence relationship of gill congeneric ectoparasites: testing the core satellite hypothesis and ecological specialisation. Parasitol Res, 88, 682, 2002. 
24. TU X., LING F., HUANG A., WANG G. The first report of Dactylogyrus formosus Kulwiec, 1927 (Monogenea: Dactylogyridae) from goldfish (Carassius auratus) in central China. Parasitol Res, 114 (7), 2689, 2015.

25. SHARMA P., AGARWAL N., KUMAR S. Ribosomal DNA and morphological analysis of Dactylogyrus species from freshwater fish of India. J Parasit Dis, 35 (2), 210, 2011.

26. ALARCOS A.J., TIMI J.T. Parasite communities in three sympatric flounder species (Pleuronectiformes: Paralichthyidae): similar ecological filters driving toward repeatable assemblages. . Parasitol Res 110 (6), 2155, 2012.

27. NEVES L.R., PEREIRA F.B., TAVARES-DIAS M., LUQUE J.L. Seasonal influence on the parasite fauna of a wild population of Astronotus ocellatus (Perciformes: Cichlidae) from the Brazilian Amazon. . J Parasitol, 99 (4), 718, 2013.

28. PANTOJA W.M.F., SILVA L.V.F., TAVARES-DIAS M. Are similar the parasite communities structure of Trachelyopterus coriaceus and Trachelyopterus galeatus (Siluriformes: Auchenipteridae) in the Amazon basin? . Rev Bras Parasitol Vet, 25 (1), 46, 2016.

29. LUUS-POWELL W.J., MAHLANGU P.S., THERON J., HATTINGH H. Gyrodactyliasis - a cause for concern? . J S Afr Vet Assoc, 80, 123, 2009.

30. VIOLLE C., ENQUIST B.J., MCGILL B.J., JIANG L., ALBERT C.H., et al. The return of the variance: intraspecific variability in community ecology. Trends Ecol Evol, 27 (4), 244, 2012.

31. CARVALLHOA R.P.S., TAKEMOTOB R.M., MELOC C.M., JERALDOC V.L.S., MADIC R.R. Structure of the parasite infracommunity of Sciades proops from the Japaratuba River Estuary, Sergipe, Brazil. Braz J Biol 75 (4), 906, 2015.

32. MADI R.R., UETA M.T. Fish parasites as environmental indicators. In: SILVA-SOUZA A.T., LIZAMA M.A.P., TAKEMOTO R.M., editors. Pathology and health of aquatic organisms. Maringá: Massoni. 33, 2012.

33. DOGIEL V.A. Ecology of the parasites of freshwater fish in Parasitology of fish. 1, 1961.

34. RICHARDS E.L., VAN OOSTERHOUT C., CABLE J. Sex-specific differences in shoaling affect parasite transmission in guppies. . PLoS ONE 5 (10), el3285, 2010.

35. RICHARDS E., VAN OOSTERHOUT C., CABLE J. Interactions between males guppies facilitates the transmission of the monogenean ectoparasite Gyrodactylus turnbulli. Exp Parasitol, 132, 483, 2012.

36. NASRADDIN M.O. Some Ecological Aspects of Monogenean Infections on Some Fish from Lesser Zab River, Near Koysinjaq City, Kurdistan Region, Iraq [M.Sc.]: Salahaddin University. 126, 2013.

37. ABDULLAH S.M.A., MHAISEN F.T. Effects of sex and length of Cyprinus carpio from Lesser Zab River in northern Iraq, and seasonal variations on the infection with some parasites. Al-Rafidain J Sci, 17 (9), 1, 2006.
38. ABDULLAH S.M.A. First record of Dactylogyrus rectotrabus (Monogenetic Trematoda) from Garra rufa from Greater Zab River, North of Iraq, regarding its ecological aspects. 1029, 2007.

39. ÖZER A., ÖZTURK T. Dactylogyrus cornu Linstow, 1878 (Monogenea) infestations on Vimba vimba tenella (Nordmann, 1840) caught in the Sinop region of Turkey inrelation to the host factors. Turk J Vet Anim Sci, 29, 1119, 2005.

40. NEARY E.T., DEVELI N., ÖZGUL G. Occurrence of Dactylogyrus species (Platyhelminths, Monogenean) on Cyprinids in Almus Dam Lake, Turkey. Turk J Fisher Aquatic Sci, 12, 15, 2012.

41. CRAFFORD D., LUUS-POWELL W.J., AVENANTOLDEWAGE A. Monogenean parasites from fish of the Vaal Dam, Gauteng Province, South Africa II. New locality records. Acta Parasitol, 59 (3), 485, 2014.

42. SCHADE F.M., RAUPACH M.J., MATHIAS WEGNER K. Seasonal variation in parasite infection patterns of marine fish species from the Northern Wadden Sea in relation to interannual temperature fluctuations. J Sea Res, 113, 73, 2016.

43. HOLT R.E., JøRGENSEN C. Climate change in fish: effects of respiratory constraints on optimal life history and behaviour. Biol Letters, 11 (2), 2015.

44. RAISSY M., ANSARI M. Parasites of Some Freshwater Fish from Armand River, Chaharmahal va Bakhtyari Province, Iran Iran J Parasitol, 7 (1), 73, 2012.

45. MORAND S., KRASNOV B.R., LITTLEWOOD D.T.J. Parasite Diversity and Diversification Evolutionary Ecology Meets Phylogenetics. Cambridge University: Cambridge CB2 8BS. 508, 2015.

46. KADLEC D., SIMKOVA A., JARKOVSKY J., GELNAR M. Parasite communities of freshwater fish under flood conditions. Parasitol Res, 89 (4), 272, 2003.

47. MORRIS E.K., CARUSO T., BUSCOT F., FISCHER M., HANCOCK C., et al. Choosing and using diversity indices: insights for ecological applications from the German Biodiversity Exploratories. Ecol Evol, 4 (18), 3514, 2014.

48. TURGUT E., SHINN A., WOOTTEN R. Spatial Distribution of Dactylogyrus (Monogenan) on the Gills of the Host Fish Turkish J Fisheries Aqu Sci, 6, 93, 2006.

49. BLAŽEK R., JARKOVSKÝ J., KOUBKOVá B., GELNAR M. Seasonal variation in parasite occurrence and microhabitat distribution of monogenean parasites of gudgeon Gobio gobio (L.). Helminthol, 45 (4), 185, 2008.

50. BLAHOUA G.K., ADOU E.Y., ETILE N.R., YAO S.S., N'DOUBA V. Occurrence of Gill Monogenean Parasites in Redbelly tilapia, Tilapia zillii (Teleostei: Cichlidae) from Lobo River, Côte d'Ivoire J Animal Plant Sci, 35 (3), 5674, 2018.

51. TRIPATHI P., AGRAWAL N., PANT R., AGRAWAL G.G. Microhabitat distribution of some monogenoideans, parasitizing the gills of Wallago attu (Bi. and Sch., 1801) and their seasonal variation. J Parasit Dis, 34, 24, 2010. 